\title{
POPULATION DYNAMIC OF THE BROWN SOFT SCALE, Coccus hesperidum L. (HEMIPTERA: COCCIDAE) INFESTING THE ORNAMENTAL PLANT, Nerium oleander UNDER ASSIUT GOVERNORATE CONDITIONS. \\ Ghada S. Mohamed \\ Department of Plant Protection, Faculty of Agriculture, South Valley University
}

\begin{abstract}
The ornamental plant Nerium oleander L. was inspected as a host of the brown soft scale, Coccus hesperidum L. The present study was carried out in the Farm of Faculty of Agriculture, Assiut University, during two successive seasons of 2012/2013 and 2013/2014. Data from both seasons revealed that the highest numbers of nymphs and the total number of the pest were recorded during the $1^{\text {st }}$ week of August. The highest percentages of the total monthly mean count (out of the total year count) were found to be 21.11 and $19.45 \%$, in July during the $1^{\text {st }}$ and $2^{\text {nd }}$ years. In addition, it has four generations per year under field conditions. Metaphycus luteolus Timberlake was the only wasp species found to parasitize on C. hesperidum. Parasitism rate reached $5.31 \%$ during the first year of the study. The brown soft scale was able to resist parasitization by encapsulating the parasitoid's eggs. Maximum encapsulation rate was estimated up to $2.19 \%$ of adult scales. Predation rate reached $3 \%$ and it was attributed to the coccinellid, Chilocorus bipustulatus $(L)$. The effects of weather elements on the pest population were also possible. This aforementioned information can be taken into consideration when developing a plan for sustainable control strategy for this pest in Egypt.
\end{abstract}

\section{INTRODUCTION}

Oleander plant, Nerium oleander $\mathrm{L}$. is an ornamental plant belonging to the family Apocynoideae. The plant grows well in worm subtropical regions, where it is extensively used as ornamental plant in landscape, parks, and along roadsides.

Scale insects are notorious pests of ornamental plants, particularly perennials. They cause damage by feeding on plant sap, reducing vigour and producing chlorotic areas at feeding locations, premature leaf drop, and distorting stems and bark. Large population of scale insects can kill branches and heavily infestations may kill trees. The sugar-rich honeydew produced by the Coccoidea pests provides a medium for the growth of sooty mould. This mould covers the leaves with a black infected coating of mycelia, which interferes with photosynthesis, causing the plants to decline in vigour and to lose their aesthetic value (Selma and Hasan, 2004). Also, indirect damage represents in the injection of toxins into the host and some insects serve as viral vectors. As far as its biology is concerned, females are reproducing 


\section{Ghada S. Mohamed}

parthenogentically (Ben-Dov 1993). Males may occur in the population at a low proportion. Its entire life cycle is spent on the lower leaf surface (Gill 1988). The population fluctuation of the brown soft scale, Coccus hesperidum $\mathrm{L}$ was studied by many authors in different locations (e.g. BenDov and Hodgoson, 1997 and Malais and Ravensberg, 2003) on fruit plants, however, such studies on ornamental plants are very limited especially in Egypt.

Many parasitoids mainly encyrtids, Metaphycus sp., (Blumberg and DeBach, 1981; Guerierri and Noyes, 2000 and Kapranas, 2002) and a few coccinellid predators (Elmer and Brawner, 1975 and Abd-Rabou and Badary, 2005) have been reported to act against $C$. hesperidum. Variable encapsulation rates of many parasitoid eggs by $C$. hesperidum have been demonstrated in other studies (Blumberg and DeBach, 1981 and Bernal et al., 1999). The encapsulation frequency depends on several factors, such as the host plant, the temperature, the age or the species of the scale insect pest and supperparasitism. The encapsulation rates of two parasitoids (Metaphycus swirskii and Encyrtus lecanorium) by $C$. hesperidum were lower in young female scales than in mature ones (Blumberg 1982, Blumberg and Goldenburg 1991). Superparasitism reduces the encapsulation frequency due to the weakness of the parasitized scale. The $C$. hesperidum which had been weakened by Coccophagus sp. parasitism was not able to encapsulate eggs of M. swirskii (Blumberg 1982). This resistance to parasitization which occurred by encapsulation has been regarded as the main cause of the inability of many parasitoids to prevent outbreaks of the pest (Blumberg 1991).

The present work aims to study some ecological aspects of $C$. hesperidum under Assiut governorate conditions concerning the predators and parasitoids of the scale insect pest as well as their activity, the possibility of the scale to control the development of parasitoids by encapsulation, the frequency and seasonal fluctuation of encapsulation and the age of the scale and the parasitoid in which encapsulation occurs.

\section{MATERIALS AND METHODS}

The present study was carried out in the Farm of the Faculty of Agriculture, Assiut University during two successive seasons of 2012/2013 and 2013/2014. The normal agricultural practices were performed and no insecticides were used during the period from July, 2012 to June, 2014. Five plants of $N$. oleander were randomly chosen on successive weeks. Five leaves of each tree were picked up randomly forming 25 leaves as a sample kept in a polyethylene bag, then transferred into the laboratory for examination. The lower surfaces of leaves were examined under a stereomicroscope of 10-60 magnification power. The numbers of all scales of each instar as well the numbers of predated and parasitized scales were recorded. As predated scales were recorded only the partially destroyed ones (the half-eaten scales) because the totally consumed individuals (such as crawlers) obviously could not be estimated. The meaning of "Percent 
Parasitism" (\% PA) in studies of insect parasitoids was described by Van Driesche (1983) and calculated as follows:

$$
\% \mathrm{PA}=\frac{\mathrm{EMP}+\mathrm{LP}}{\mathrm{EMP}+\mathrm{LP}+\mathrm{UMH}}
$$

Where EMP $=$ emerged parasitoids, $\mathrm{LP}=$ all live parasitoids and $\mathrm{UMH}$ $=$ unparasitized brown soft scale hosts. To simplify the formula EMP $+L P=$ total parasitized hosts, EMP + LP + UMH= total brown soft scale hosts.

Females containing one or more encapsulated (melanized) parasitoid eggs were also noted. Dark encapsulated eggs were easily distinguished inside the transparent yellowish scale body. Encapsulation frequency was assessed as follow: scales;

1. Scales containing encapsulated eggs as percentage (\%) of live adult

2. Percentage parasitized scales wherein encapsulation completely prevented parasitoid development, which reflects the rate of efficient encapsulation (Ee): (Blumberg 1991)

$$
\mathrm{Ee}=\frac{\text { Scales with encapsulated egg only }}{\text { Total number of parasitized scales }} \times 100
$$

To identify the pest parasitoid, each plant sample (10 leaves from each plant (5 plants)), after the examination of plant leaves in the laboratory for counting the nymphs and adults of the pest, were stored in a one pound glass Jar (10 glass jars weekly). The jar was furnished with a suitable disc of filter paper on its bottom to absorb condensed humidity. Jars were covered with a piece of polyethylene with minute holes held by means of rubber band. A piece of cotton-wool soaked in $10 \%$ sucrose solution was placed in a small plastic container and placed inside the jar for feeding the emerged parasitoids. The emerged parasitoids were then collected and kept in a wellventilated small tubes containing alcohol $70 \%$ and transferred into the Biological Control Research Department, Plant Protection Institute, Ministry of Agriculture, Egypt, for identification by Dr. A. Raouf.

Insect generation is defined, as the time needed to complete its life cycle. The number and duration of the annual generations of the pest, which were estimated depending on the adult numbers of the insect weekly count, were worked out according to Audemard and Milaire (1975) formula.

\section{RESULTS AND DISCUSSION}

Seasonal density monitoring. Data (Tables (1 and 4$)$ show the weekly population counts and the monthly incidence of the brown soft scale (nymphs and adults) on $N$. oleander leaves during both seasons of 2012/2013 and 2013/2014. 
Ghada S. Mohamed

1

1112 
J. Plant Prot. and Path., Mansoura Univ., Vol. 5 (12), December, 2014

1

1113 


\section{Ghada S. Mohamed}

Season 2012/2013: Data presented in Table (1) indicated that the brown soft scale population started the season with a very high population and quickly reached its high population. The highest numbers of brown soft scale nymphs and the total population (nymphs and adults) were recorded during the first week of August (383 and 482 individuals/25 leaves) while the highest number of adults was recorded during the third week of November (127 individuals/25 leaves). The population decreased after December till May when no single nymph was recorded during the second week of February. However, both nymphs and adults were recorded again during the last week of March. Results in Table (2) showed that the highest percentage of brown soft scale (nymphs and adults) was recorded during July $(21.11 \%$ of the total count of the year), while the lowest one was reported during April $(0.40 \%)$. It is clear that the brown soft scale populations were recorded at their high rates from July till December, then, decreased sharply to reach its low percentage during February $(0.51 \%$ of the total year count). The population of $C$. hesperidum (nymphs and adult) started to increase on June (4.66\% of the total year count).

Table (2): The monthly incidence of $C$. hesperidum stages and their percentages out of the year total during 2012/2013.

\begin{tabular}{|l|c|c|c|c|}
\hline \multirow{2}{*}{ Month } & \multicolumn{4}{|c|}{ Insect count/25 leaves } \\
\cline { 2 - 5 } & Nymphs & Adults & Total & $\begin{array}{c}\text { \% out of } \\
\text { year total }\end{array}$ \\
\hline July, 2012 & 1622 & 379 & 2001 & 21.11 \\
\hline August & 1229 & 286 & 1515 & 15.98 \\
\hline September & 981 & 251 & 1232 & 13.00 \\
\hline October & 1005 & 263 & 1268 & 13.38 \\
\hline November & 886 & 455 & 1341 & 14.15 \\
\hline December & 707 & 300 & 1007 & 10.62 \\
\hline January, 2013 & 106 & 358 & 464 & 4.90 \\
\hline February & 7 & 42 & 49 & 0.51 \\
\hline March & 15 & 53 & 68 & 0.72 \\
\hline April & 23 & 16 & 39 & 0.40 \\
\hline May & 38 & 15 & 53 & 0.56 \\
\hline June & 353 & 89 & 442 & 4.66 \\
\hline Total & 6972 & 2507 & 9479 & 100 \\
\hline
\end{tabular}

Season 2013/2014: Data in Table (3) indicated that the same trend of the insect seasonal population occurred during the first season was approximately repeated during the second one. The highest numbers of nymphs and the total ones (nymphs and adults) were occurred during the first week of August (386 and 499 individuals/25 leaves). The brown soft scale population decreased after December and did not record during the first week of March and the third week of April. A slight increase was occurred again during June. 
J. Plant Prot. and Path., Mansoura Univ., Vol. 5 (12), December, 2014

3

1115 
Ghada S. Mohamed

3

1116 
Results in Table (4) showed that the highest percentages of both nymphs and adults were occurred during July and August (19.45 and 18.42\% of the total year count) and the lowest one was occurred during April (0.33). The population of the brown soft scale started the season on July with its high incidence percentage $(19.45 \%$ of the total year count), then the population fluctuated around this percentage till December. After December, the population decreased to reach its low percentage during April $(0.33 \%$ of the total year count), and then a very slight increase was occurred on June, to follow a sequence growth.

Results of both seasons clearly indicated that the population of brown soft scale was in its high population during July. Its population stayed in high level till December. The population decreased after December to reach its low level during April. The population achieved its increase during May and June. These results are in full agreement with those obtained by Annecke (1966) who reported that there is a peak of infestation with $C$. hesperidum from the beginning of July until autumn. Also, Hart and Ingle (1971) stated that $C$. hesperidum population was high during July-November and low from December-June

Table (4): The monthly incidence of $C$. hesperidum stages and their percentages out of the year total during 2013/2014.

\begin{tabular}{|l|c|c|c|c|}
\hline \multirow{2}{*}{ Month } & \multicolumn{4}{|c|}{ Insect count/25 leaves } \\
\cline { 2 - 5 } & Nymphs & Adults & Total & $\begin{array}{c}\text { \% out of } \\
\text { year total }\end{array}$ \\
\hline July, 2013 & 1301 & 326 & 1627 & 19.45 \\
\hline August & 1228 & 312 & 1540 & 18.42 \\
\hline September & 966 & 260 & 1226 & 14.66 \\
\hline October & 782 & 226 & 1008 & 12.05 \\
\hline November & 852 & 427 & 1279 & 15.29 \\
\hline December & 645 & 302 & 947 & 11.32 \\
\hline January, 2014 & 107 & 347 & 454 & 5.44 \\
\hline February & 11 & 52 & 63 & 0.75 \\
\hline March & 15 & 49 & 64 & 0.77 \\
\hline April & 17 & 11 & 28 & 0.33 \\
\hline May & 33 & 21 & 54 & 0.65 \\
\hline June & 58 & 15 & 73 & 0.87 \\
\hline Total & 6015 & 2348 & 8363 & 100 \\
\hline
\end{tabular}

The numbers of brown soft scale adults on $N$. oleander leaves during $2012 / 2013$ and $2013 / 2014$ seasons were used to determine the number of their generations according to Audemard and Milaire (1975) this method was used to determine the number of field generations either for coccoideae pests or others by many investigators. Abd-Rabou and Mostafa (2010) used this method to determine the number of field generations of the oyster shell olive scale, Leucaspis riccae. Hassanein and Salman (2009) determined the number of field generations of the pubescent rose chafer, Tropinota squalida (Scop.). The number of generations is shown in Figure (1). Illustration in Figure $(1, A)$ revealed the occurrence of four generations. Adults of the $1^{\text {st }}$ 


\section{Ghada S. Mohamed}

generation were appeared in the field during the period from July, 2 to August, 27. This generation lasted 56 days. The $2^{\text {nd }}$ generation started from September, 3 to November, 19 and lasted 77 days. The third generation was observed from November, 26 to February, 4 and lasted 70 days. The last generation lasted 139 days and appeared from February, 11 to June, 30; whereas illustration in Figure $(1, B)$ showed also four generations for $C$. hesperidum during this season. The $1^{\text {st }}$ generation was observed from July, 7 to August, 18 and lasted 42 days. The $2^{\text {nd }}$ generation began from August, 25 to November, 10 and lasted 77 days. The $3^{\text {rd }}$ generation was observed in the field from November, 17 to January, 26 and lasted 71 days. The last one occupied the period from February, 9 to June, 29 and lasted 140 days.
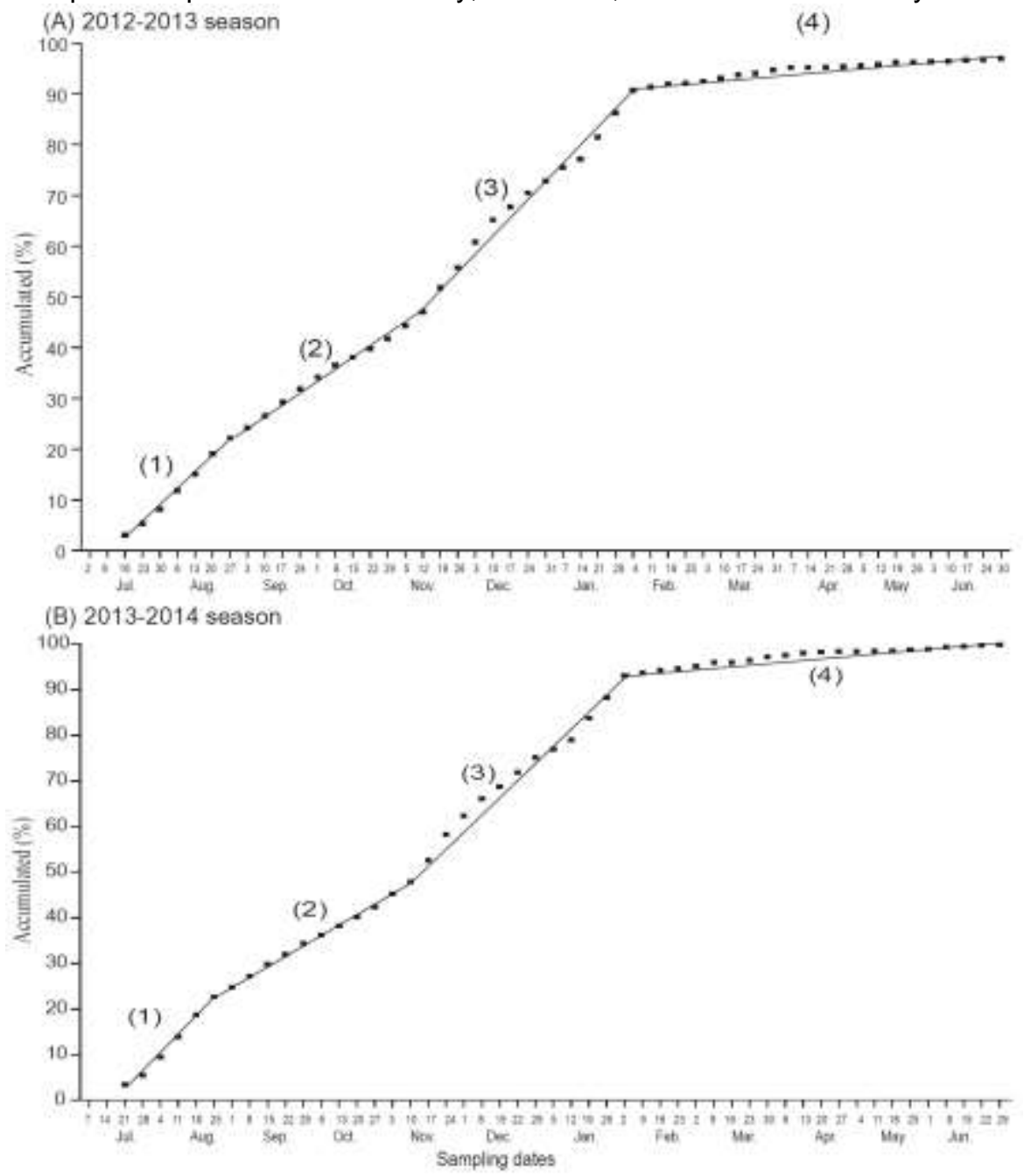

Fig. (1):Number of Coccus hesperidum adults field generations, arranged according to Audemard and Milaire (1975) method during 2012/2013 and 2013/2014 seasons, at Assiut governorate. 
Results of both seasons revealed that there is four generations for $C$. hesperidum on $N$. oleander leaves at Assiut region. The shortest generation was the $1^{\text {st }}$ one where the temperature was in its high levels during the period of this generation. Many authors (e.g. Nakahara, 1976 and Malais and Ravensberg, 2003) arrived to the same result in which the brown scale insect has four yearly generations. In additions, some other authors (e. g. Gill, 1988; Kosztarab, 1996 and Johnson, 2002) revealed that the pest has 3-5 generations a year. The conflict in the results may be due to the differences in the regions and consequently differences in climatic elements, the differences in host plants and cultural practices.

Data of the two seasons in Table (5) revealed that the most effective weather variables were minimum temperature and relative humidity during the first season, and the relative humidity and minimum temperature during the second one. Johnson (2002) found that the most important factor affecting the population numbers of $C$. hesperidum was temperature especially if combined with low humidity.

Table (5): Multiple regression analysis between the total number of the brown soft scale insect, $C$. hesperidum and some weather factors prevailing at Assiut region during 2012/2013 and 2013/2014 seasons.

\begin{tabular}{|c|c|c|c|c|c|c|}
\hline $\begin{array}{l}\text { Growing } \\
\text { season }\end{array}$ & $\begin{array}{l}\text { Weather } \\
\text { factors }\end{array}$ & $\mathbf{r}$ & $\mathbf{R}$ & $R^{2} \times 100$ & \begin{tabular}{|l|} 
Decrease \\
in $R^{2} \times 100$
\end{tabular} & Efficiency \\
\hline \multirow{4}{*}{$\begin{array}{l}\overline{\mathbf{D}} \\
\stackrel{N}{N} \\
\overline{0}\end{array}$} & Non & - & 0.8023 & 64.38 & & 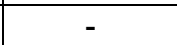 \\
\hline & Max. temp. $\left(\mathrm{X}_{1}\right)$ & +0.2307 & 0.7878 & 62.07 & 2.31 & 2.7979 \\
\hline & Min. temp. $\left(\mathrm{X}_{2}\right)$ & $+0.5601^{* *}$ & 0.4555 & 20.74 & 43.64 & 52.8321 \\
\hline & $\begin{array}{c}\text { Avg. R.H. \% } \\
\left(\mathrm{X}_{3}\right)\end{array}$ & -0.0091 & 0.7560 & 57.15 & 7.23 & 8.7512 \\
\hline \multirow{4}{*}{ 商 } & Non & - & 0.6624 & 43.88 & - & \\
\hline & Max. temp. $\left(\mathrm{X}_{1}\right)$ & $+0.3780^{\star *}$ & 0.6296 & 39.64 & 4.24 & 4.9477 \\
\hline & Min. temp. $\left(\mathrm{X}_{2}\right)$ & $+0.4320^{* *}$ & 0.5941 & 35.30 & 8.58 & 10.0108 \\
\hline & $\begin{array}{l}\text { Avg. R.H. \% } \\
\left(\mathrm{X}_{3}\right)\end{array}$ & -0.1383 & 0.4368 & 19.08 & 24.80 & 23.926 \\
\hline
\end{tabular}

$r=$ Simple correlation.

$\mathbf{R}=$ Multiple regression.

$\mathbf{R}^{2}=$ Coefficient of determination.

${ }^{* *}=$ Highly significant at 0.01 level of probability.

Parasitized scales are presented in Tables (1 and 3). Parasitism was recorded only in adult scale and it was attributed to Metaphycus luteolus Timberlake (Hymenoptera: Encyrtidae), since this was the only parasitoid that emerged from parasitized scale. Parasitism rate was maximized during July 2012 (5.31\%), and July 2013 (3.96\%). Among the parasitoids which are referred as natural enemies of the brown soft scale in bibliographies, three species only are reported in several areas in Egypt, and they are Metaphycus luteolus, $M$.helvolus and M. flavus (Abd-Rabou, 2006). Metaphycus luteolus have been collected from infested black scale Saissetia oleae (Oliver) 


\section{Ghada S. Mohamed}

(Kennett, 1986). The former species was the sole wasp recorded during the present study causing notable parasitism to the coccid demonstrating two peaks in July 2012 (5.31\%), and in July 2013 (3.96\%). This regarded as quite an increased parasitism rate when compared with the respective rates by $M$. stanleyi (10 - 12\%) (Blumberg and Blumberg, 1991) and the parasitoid complex of Metaphycus sp., Coccophagus sp. (Hymenoptera: Aphelinidae) and Tetrastichus sp. (Hymenoptera: Eulophidae) (25.2\%) (Toit et al. 1991). Results showed that the numbers of this parasitoid was low and in the same line with Kapranas et al. (2007) and Mohamed et al. (2013) where they reported that although this parasitoid was common, its numbers peaked only sporadically, and never abundant in relation to $C$. hesperidum densities. Also, the percentages of parasitism were low which ranged from 7 to $11 \%$ during both seasons. This means that this parasitoid species is not established yet at Assiut Governorate because it worked well in established regions, although it discovered latterly in some of these regions because of the suitability of temperature and relative humidity. Where the parasitoid is the predominant agent in biological control of $C$. hesperidum, the percentages of parasitism were high which ranged from 60 to $83.5 \%$ during both seasons in Israel (Blumberg and Goldenburg, 1991). Nectar from plants has often proved to be a good adult food source, as indicated by improved parasitoid lifespan and fecundity (Saakyan, 1964 and Davoodi, 2004).

The brown soft scale was able to resist parasitization by encapsulating the parasitoid's eggs. It reacted to Metaphycus luteolus parasitism by encapsulating the parasitoid egg. The highest levels of encapsulation were recorded during summer (July 2012 and August 2013) reaching $2.19 \%$ and $1.93 \%$ of adult scales (Table 1 and 3). Encapsulation was observed only at the egg of the parasitoid, which means that parasitoid development was entirely prevented. Encapsulation rate reached $2.19-1.93 \%$ of adult scales. It is evident that encapsulation by scales infesting Nerium oleander at Assiut region is significantly less intense compared to that by scales infesting other ornamental plants (28-65\%) and avocado trees (49-62\%) (kapranas and Luck, 2008 and kapranas et al., 2009 ), in USA. Taking into consideration that encapsulation is significantly influenced not only by ambient temperature, but also by parasitoid species (Salt, 1963) the differences among those studies and the current one may be explained. The abovementioned studies were conducted in USA, an area with colder climate than Assiut, Egypt, and dealt with various parasitoids species other than $M$. luteolus, such as its conspecifics $M$. helvolus, $M$. swirskii and $M$. galbus. Although, it is very probable that most encapsulated eggs observed during the present study belong to $M$. luteolus, the author cannot exclude the possibility that other parasitoids failed to complete development inside $C$. hesperidum due to the encapsulation of their eggs. This difference in the numbers of encapsulated eggs could be attributed to differences in host scale insects, parasitoid species and host plants. The fact that encapsulation rate was high during summer is in agreement with the results of other studies in which encapsulation was more frequent in summer than in other seasons (Blumberg, 1997). 
The presence of predated individuals of $C$. hesperidum is attributed to the action of Chilocorus bipustulatus which proved to be the sole predatory insect observed during the present study. However, these data refer only to partially destroyed scales and do not include totally consumed individuals such as crawlers that obviously cannot be estimated. Predated scales are reached to the highest during July 2012 and July 2013 and reached to 3\% and $2.61 \%$ of total scales (Tables 1 and 2). The presence of $C$. bipustulatus has also been noted on infested by $C$. hesperidum citrus trees in Turkey (Elecioglu and Derya, 2007). Other coccinellids such as Hyperaspis sp. and C. angolensis (Robertson et al. 1986), C. nigrita (Fabricius) and Exochomus quadripustulatus (L.)(Dixon, 2000) and Chrysoperla carnea (Stephens) (Swirski et al. 1997) have also been reported to feed upon C. hesperidum.

The data of the present study give some information concerning the phenology and ecology of $C$. hesperidum which is considered a new pest in Assiut area. Although the scale is found at present only on oleander shrubs, it could be considered as a potential serious pest, as it referred as important pest of fruit tree and ornamental plants in many parts of the world (Ben-Dov, 1993). The data of phenology show that the scale insect is active throughout the year completing several overlapping generations. The predator C. bipustulatus could not result in any significant reduction of the pest. In addition, the action of the parasitoid $M$. luteolus was higher than that of the predator even thought it could not be able to control the pest where the infestation levels were found similar in both years. The study on encapsulation is giving important information on the ecology of this pest, as it is known that a high rate of encapsulation of Metaphycus spp. eggs by $C$. hesperidum during the summer that may interfere with the efficient biological control of the pest (Blumberg, 1997).

\section{REFERENCES}

Abd-Rabou, S. (2006): Hymenoptera parasitoids as a bioagent for controlling homopterous insect in Egypt. Egypt. J. Agric. Res. 6: 1-59.

Abd-Rabou, S. and Badary, H. (2005): Natural enemies of the soft brown scale, Coccus hesperidum L. (Homoptera: Coccidae) in Egypt. Egypt. J. Agric.Res.83 (1): 77-87.

Abd-Rabou, S. and M. Mostafa (2010): Incidence of the oyster shell olive scale, Leucaspis riccae (Hemiptera: Diaspididae) and its parasitoids with a survey of the scale insects infesting olive trees in Egypt. The 5 th Scientific Conference for Agricultural Sciences Fac.Agric. Assiut Univ. Dct. 16-17. (211-225).

Annecke, D. P. (1966): Biological studies on the immature stages of Brown Soft Scale, Coccus hesperidum L. (Homoptera: Coccidae). South African Journal of Agricultural Science 9: 205-228. 


\section{Ghada S. Mohamed}

Audemard, H. and Milaire, H. G. (1975): Le piégeage du Carpocapse (Laspeyresia pomonella L.) avec une phéromone sexuelle de synthése. Premiers résultants utilisables pour 1éstimation des populations et al conduite de la lutte. Ann. Zool. Écol. Anim., 7(1):6180.

Ben-Dov, Y. (1993): A systematic catalogue of the soft scale insects of the world (Homoptera: Coccoidea: Coccidae) with data on geographical distribution, host plants, biology and economic importance. Flora and Fauna Handbook, No.9. Sandhill Crane Press,Gainesville..

Ben-Dov, Y. and Hodoson, C. J. (1997): Scale Insects: Their Biology, Natural Enemies and Control. Volume 2. Elsevier Science, 251-442 pp.

Bernal, J. S.; Luck, R.F. and Morse, J. G. (1999): Augmentative release trials with Metaphycus spp. (Hymenoptera: Encyrtidae) against citricola scale (Homoptera: Coccidae) in California's San Joaquin Valley. Journal of Economic Entomology. 92, 1099-1107.

Blumberg, D. (1982): Further studies on the encapsulation of Metaphycus swirskii by soft scales. Entomol. Exp. Appl. 31:245-248.

Blumberg, D. (1991): Seasonal variation in the encapsulation of eggs of the encyrtid parasitoid Metaphycus stanleyi by the pyriform scale, Protopulvinaria pyriformis. Entomol. Exp. Appl. 58:231-237.

Blumberg, D. (1997): Encapsulation of parasitoids. Soft Scale Insects-Their Biology, Natural Enemies and Control (7A) (eds Y. Ben-Dov \& C.J. Hodgson), pp. 375-387. Elsevier Science B. V., Amsterdam.

Blumberg, D. and Blumberg, O. (1991): The pyriform scale, Protopulvinaria pyriformis, and its common parasitoid, Metaphycus stanleyi, on avocado and Hedera helix. Alon Hanotea 45:265-269.

Blumberg, D. and DeBach, P. (1981): Effects of temperature and host age upon the encapsulation of Metaphycus staneyi and Metaphycus helvolus eggs by brown soft scale, coccus hesperidum. J. Invertebr. Pathol. 37:73-79.

Blumberg, D. and Goldenburg, S. (1991): Encapsulation of eggs of two species of Encyrtus (Hymenoptera: Encyrtidae) by soft scales (Homoptera: Coccidae) in six parasitoid-host interactions. Israel J. Ent. 25-26:57-65.

Davoodi, A. (2004): Identification and host range of soft scale (Hom: Cooccidae) parasitoid wasps in Tehran and some other areas of Iran. M. Sc. Thesis, Tarbiat Modarres University, Tehran, Iran, 143pp.

Dixon, A.F.G. (2000): Insect Predator- Prey Dynamics, Ladybird Beetles and Biological Control. Cambridge University Press, Cambridge, p. 257.

Elecioglu, Z. and Derya, S. (2007): Pest and Natural Enemy Fauna in Organic Citrus Production in the Eastern Mediterranean Region of Turkey. International Journal of Natural and Engineering Sciences, 1: 29-34 (2007).

Elmer, H. S. and Brawner, O. L. (1975): Control of Brown Soft Scale in Central Valley. Citrograph. 60(11): 402-403.

Gill, R. J. (1988): The scale insects of California-Part 1: The Soft Scales (Homoptera: Coccoidea: Coccidae). California Department of Food and Agriculture, California. 
Guerierri, E. and Noyes, J.S. (2000): Revision of European species of genus Metaphycus mercet (Hymenoptera: Chalcidoidea: Encyrtidae), parasitoids of scale insects (Homoptera: Coccoidea). Syst. Entomol. 25:147-222.

Hart, W. G. and Ingle S. J. (1971): Increases in the Fecundity if Brown Soft Scale Exposed to Methyl Parathion. J. Econ. Entomol. 64: 204-208.

Hassanein, A. M. A. and Salman, A. M. A. (2009): Susceptibility of rose (Rosa spp.) to infestation by the pubescent rose chafer, Tropinota squalida (Scop.) and its relationship with rose cultivars and climatic changes in southern Egypt. American. Eurasian J. Agric. and Environ. Sci., 6(6):642-650.

Johnson, S. (2002): Brown soft scale: Biology and control. Association of Education and Research Greenhouse Curators 14: 5-6.

Kapranas, A. (2002): Clutch size, pattern of sex allocation and encapsulation of Metaphycus sp. nr flavus (Hymenoptera: Encyrtidae) eggs, a facultative gregarious endoparasitoid of brown soft scale, Coccus hesperidium L. (Homoptera: Coccidae), M.Sc. thesis, University of California, Riverside.

Kapranas, A. and Luck, R.F. (2008): Egg maturation, host feeding, and longevity in two Metaphycus species parasitoids of soft scale insects. Biological Control, 47, 147-153.

Kapranas, A.; Federici, B.A.; Luck, R.F. and Johnson, R.F. (2009): Cellular immune response of brown soft scale Coccus hesperidum $L$ (Hemiptera: Coccidae) to eggs of Metaphycus luteolus Timberlake (Hymenoptera: Encyrtidae).Biological Control, 48, 1-5.

Kapranas, A.; Morse, J. G.; Pacheco, P.; Forster, L.D. and Luck, R. F. (2007): Survey of brown soft scale, Coccus hesperidum parasitoids in southern California citrus. Biological Control, 42:288-299.

Kennett, C.E. (1986): A survey of the parasitoid complex attacking black scale saissetia oleae Olivier in central and northern California use hymenoptera Chalcidoidea homoptera coccidae. Pan Pacific Entomologist, 62(4):363-369.

Kosztarab, M. (1996): Scale Insects of northeastern America: Identification, Biology and Distribution. Martinsburg, Virginia, Virginia Museum of Natural History. 650 pp.

Malais, M. H. and Ravensberg, W. J. (2003): Knowing and recognizing: the biology of glasshouse pests and their natural enemies. Reed Business Information, Koppert B. V., The Netherland.

Mohamed, E.M.; Basher, A.M. And Abukaf, N. (2013): Survey of parasitoid species associated with the brown soft scale insect, Coccus hesperidum (Homoptera:coccidea) on citrus trees Lattakia, Syria. Egyptian Journal of Biological Pest Control, 23 (1), 2013, 25-29.

Nakahara, S. (1976): Brown Soft Scale, Coccus hesperidum Linnaeus. pp. 93-94. In: Syllabus for Workshop on Scale Insect Identification. Presented at the National Meeting of the Entomological Society of America in Hawaii. 115 pages.

Robertson, C. M.; Villers, E. A. and De-Villiers, E. A. (1986): Parasites of avocado pest bite the dust. Citrus Subtrop. Fruit. J. 632:637. 


\section{Ghada S. Mohamed}

Saakyan B. A. A. ( 1964): On the biology of the soft scale, Coccus hesperidum L. (Homoptera: Coccidae). Entomologicheskoe Obozrenye, 43: 268-296. In Russian.

Salt, G. (1963): The defence reactions of insects to metazoan parasites. Parasitology, 53:527-642.

Selma, U. and Hasan, C. (2004): Scale insect pests on ornamental plants in urban habitats in Turkey. J. pest. Sci. 77:79-484.

Swirski, E.; Ben-Dov, Y. and Wysoki, M. (1997): Guava. In: Ben-Dov Y, Hodgson CJ (eds) Soft scale insects-their biology, natural enemies and control, world crop pests, vol 7B. Elsevier, Amsterdam, pp 255263.

Toit, W. J.; Schutte, M. S. and Steyne, W. P. (1991): Parasitoids of the heart shaped scale, Protopulvinaria pyriformis (Cockerell) (Hemiptera: Coccidae) on avocados in South Africa. Yearb South Afr Avocado Grow Assoc 14:74-77.

Van Driesche, R.G. (1983): Meaning of "Percent Parasitism"in studies of Insect Parasitoids. Environ. Entomol.12: 1611 - 1622.

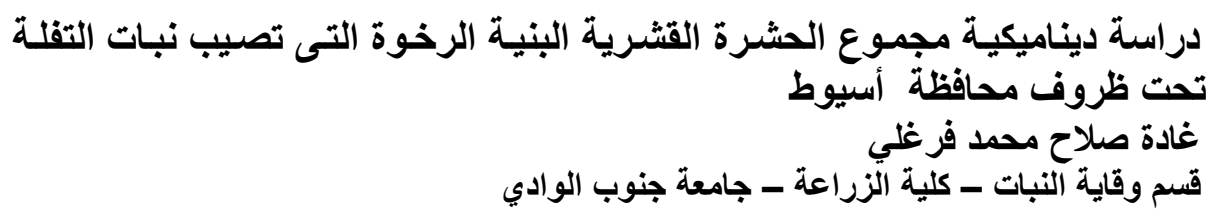

تم إجراء هذه الدراسـة فى المزرعـة البحثيـة التابعـة لكلية الزر اعـة بجامعـة اسيوط خـلال

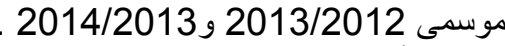

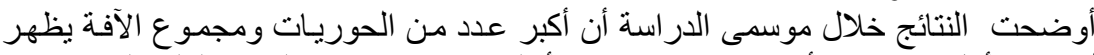

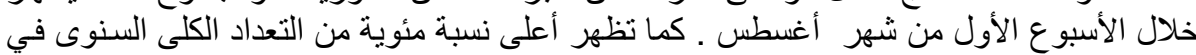

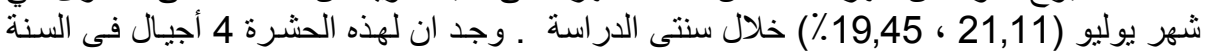

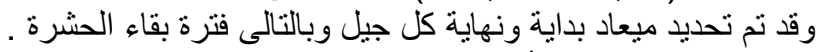

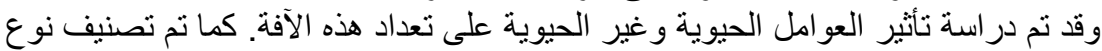

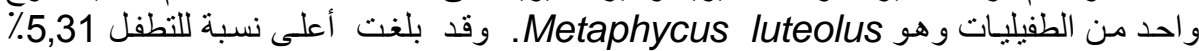

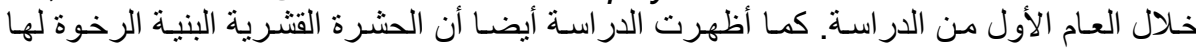

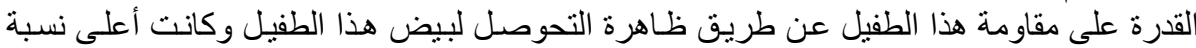

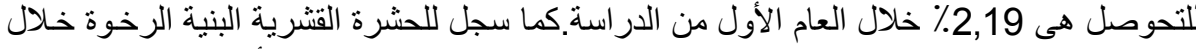

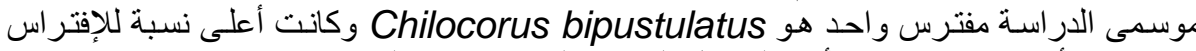
3\% كما أمكن ايضا دراسة تأثير العو امل الجوية على تعداد هذه الحشرة. 
J. Plant Prot. and Path., Mansoura Univ., Vol. 5 (12): 1109 - 1124, 2014

Table (1): Population fluctuations of the brown soft scale, Coccus hesperidum its parasitoid, M. Iuteolus, encapsulated eggs, and its predator, Chilocorus bipustulatus on ornamental plant during 2012/2013 seasons, at Assiut governorate.

\begin{tabular}{|c|c|c|c|c|c|c|c|c|c|c|c|c|c|}
\hline \multirow{3}{*}{$\begin{array}{l}\text { Month and } \\
\text { year }\end{array}$} & \multirow{3}{*}{ Date } & \multicolumn{6}{|c|}{ Weakly insect count/ 25 leaves } & \multirow{3}{*}{$\begin{array}{c}\% \\
\text { parasitism }\end{array}$} & \multirow{3}{*}{$\begin{array}{c}\% \\
\text { Efficient } \\
\text { encapsula } \\
\text { tion }\end{array}$} & \multirow{3}{*}{$\begin{array}{c}\% \\
\text { predat } \\
\text { es }\end{array}$} & \multicolumn{3}{|c|}{ Meteorological records } \\
\hline & & \multirow[t]{2}{*}{ Nymphs } & \multirow[t]{2}{*}{ Adults } & \multirow[t]{2}{*}{ Total } & \multirow{2}{*}{$\begin{array}{c}\text { parasitized } \\
\text { (No. of } \\
\text { adults) }\end{array}$} & \multirow{2}{*}{$\begin{array}{c}\text { Efficient } \\
\text { encapsul } \\
\text { ation }\end{array}$} & \multirow{2}{*}{$\begin{array}{l}\text { predated } \\
\text { (No. of } \\
\text { adults) }\end{array}$} & & & & $\begin{array}{r}\text { Tempe } \\
\left(^{\circ}\right.\end{array}$ & ature & R.H \\
\hline & & & & & & & & & & & Max. & Min. & $\%$ \\
\hline \multirow[t]{5}{*}{ July, 2012} & 2 & 312 & 76 & 388 & 25 & 2 & 62 & \multirow{5}{*}{5.31} & \multirow{5}{*}{2.19} & \multirow{5}{*}{3.00} & 40.4 & 22.4 & 40.5 \\
\hline & 9 & 275 & 57 & 332 & 13 & 3 & 54 & & & & 42.4 & 22.8 & 40.5 \\
\hline & 16 & 329 & 72 & 401 & 33 & 3 & 51 & & & & 37.4 & 21.6 & 42.79 \\
\hline & 23 & 330 & 91 & 421 & 35 & 2 & 51 & & & & 41 & 20.2 & 43.43 \\
\hline & 30 & 376 & 83 & 459 & 27 & 1 & 66 & & & & 38.8 & 22 & 45.64 \\
\hline Total & & 1622 & 379 & 2001 & 133 & 11 & 284 & & & & & & \\
\hline \multirow[t]{4}{*}{ August } & 6 & 383 & 99 & 482 & 33 & 2 & 15 & \multirow{4}{*}{3.35} & \multirow{4}{*}{1.20} & \multirow{4}{*}{0.55} & 41.2 & 21.8 & 46.29 \\
\hline & 13 & 331 & 78 & 409 & 25 & 1 & 11 & & & & 39 & 23 & 51.5 \\
\hline & 20 & 254 & 50 & 304 & 13 & 2 & 12 & & & & 38.4 & 21.4 & 52 \\
\hline & 27 & 261 & 59 & 320 & 13 & 1 & 14 & & & & 40 & 21.2 & 46.57 \\
\hline Total & & 1229 & 286 & 1515 & 84 & 6 & 52 & & & & & & \\
\hline September & 3 & 265 & 68 & 333 & 12 & 2 & 15 & \multirow{4}{*}{1.83} & \multirow{4}{*}{1.00} & \multirow{4}{*}{0.47} & 40.2 & 21.2 & 47.57 \\
\hline & 10 & 247 & 67 & 314 & 14 & 1 & 10 & & & & 40.6 & 20.2 & 51.07 \\
\hline & 17 & 238 & 58 & 296 & 9 & 0 & 9 & & & & 41.4 & 20.6 & 46.07 \\
\hline & 24 & 231 & 58 & 289 & 11 & 2 & 11 & & & & 43.2 & 18.8 & 46.43 \\
\hline Total & & 981 & 251 & 1232 & 46 & 5 & 45 & & & & & & \\
\hline October & 1 & 172 & 39 & 211 & 8 & 1 & 17 & & & & 35.8 & 17.8 & 51.64 \\
\hline & 8 & 191 & 42 & 233 & 6 & 0 & 22 & & & & 36 & 18 & 51.86 \\
\hline & 15 & 186 & 49 & 235 & 9 & 2 & 27 & 1.68 & 0.80 & 1.11 & 37.4 & 15 & 52.07 \\
\hline & 22 & 225 & 67 & 292 & 9 & 0 & 22 & & & & 39.6 & 16 & 47.43 \\
\hline & 29 & 231 & 66 & 297 & 10 & 1 & 17 & & & & 42.2 & 17.8 & 39.43 \\
\hline Total & & 1005 & 263 & 1268 & 42 & 4 & 105 & & & & & & \\
\hline November & 5 & 204 & 121 & 325 & 16 & 2 & 18 & & & & 38.6 & 14.2 & 50.43 \\
\hline & 12 & 225 & 98 & 323 & 14 & 1 & 20 & & & & 33.8 & 11.2 & 53 \\
\hline & 19 & 239 & 127 & 366 & 17 & 1 & 33 & 2.39 & 1.00 & 1.00 & 29.8 & 11.2 & 53.43 \\
\hline & 26 & 218 & 109 & 327 & 13 & 1 & 24 & & & & 29.4 & 10.2 & 59.71 \\
\hline Total & & 886 & 455 & 1341 & 60 & 5 & 95 & & & & & & \\
\hline December & 3 & 152 & 64 & 216 & 9 & 0 & 22 & & & & 26.2 & 8.8 & 57.36 \\
\hline & 10 & 165 & 70 & 235 & 10 & 1 & 26 & & & & 26.4 & 5.4 & 62.14 \\
\hline & 17 & 143 & 58 & 201 & 13 & 1 & 22 & 1.95 & 0.40 & 1.11 & 29 & 8 & 58.93 \\
\hline & 24 & 151 & 68 & 219 & 9 & 0 & 19 & & & & 25 & 2.6 & 61.29 \\
\hline & 31 & 96 & 40 & 136 & 8 & 0 & 16 & & & & 22 & 0.2 & 61.93 \\
\hline Total & & 707 & 300 & 1007 & 49 & 2 & 105 & & & & & & \\
\hline
\end{tabular}




\section{Ghada S. Mohamed}

Table (1):Cont.

\begin{tabular}{|c|c|c|c|c|c|c|c|c|c|c|c|c|c|}
\hline \begin{tabular}{|l|} 
January, \\
2013
\end{tabular} & 7 & 21 & 109 & 130 & 18 & 1 & 13 & \multirow{4}{*}{2.03} & \multirow{4}{*}{0.40} & \multirow{4}{*}{0.49} & 24.4 & 3.4 & 57 \\
\hline & 14 & 22 & 119 & 141 & 11 & 0 & 12 & & & & 21.6 & 3.6 & 58.07 \\
\hline & 21 & 62 & 112 & 174 & 18 & 1 & 18 & & & & 24.6 & 5.4 & 61.14 \\
\hline & 28 & 1 & 18 & 19 & 4 & 0 & 3 & & & & 21.2 & 4.2 & 55.14 \\
\hline Total & & 106 & 358 & 464 & 51 & 2 & 46 & & & & & & \\
\hline February & 4 & 1 & 13 & 14 & 3 & 0 & 1 & \multirow{4}{*}{0.28} & \multirow{4}{*}{0.00} & \multirow{4}{*}{0.01} & 25.8 & 4.6 & 56.21 \\
\hline & 11 & 0 & 5 & 5 & 0 & 0 & 0 & & & & 27.8 & 5.2 & 63.93 \\
\hline & 18 & 2 & 9 & 11 & 2 & 0 & 0 & & & & 24.4 & 2.2 & 64.79 \\
\hline & 25 & 4 & 15 & 19 & 2 & 0 & 0 & & & & 29.4 & 4.4 & 57 \\
\hline Total & & 7 & 42 & 49 & 7 & 0 & 1 & & & & & & \\
\hline March & 3 & 3 & 16 & 19 & 3 & 1 & 2 & \multirow{5}{*}{0.28} & \multirow{5}{*}{0.20} & \multirow{5}{*}{0.06} & 36.4 & 10 & 49.86 \\
\hline & 10 & 3 & 9 & 12 & 0 & 0 & 0 & & & & 34.2 & 7.2 & 50.79 \\
\hline & 17 & 5 & 15 & 20 & 2 & 0 & 3 & & & & 28.6 & 7.6 & 50.79 \\
\hline & 24 & 4 & 13 & 17 & 2 & 0 & 1 & & & & 30.2 & 7 & 55.5 \\
\hline & 31 & 0 & 0 & 0 & 0 & 0 & 0 & & & & 34.4 & 11.2 & 54 \\
\hline Total & & 15 & 53 & 68 & 7 & 1 & 6 & & & & & & \\
\hline April & 7 & 6 & 2 & 8 & 0 & 0 & 0 & \multirow{4}{*}{0.08} & \multirow{4}{*}{0.00} & \multirow{4}{*}{0.01} & 35.4 & 10 & 49.71 \\
\hline & 14 & 11 & 3 & 14 & 0 & 0 & 1 & & & & 34.4 & 7 & 47.21 \\
\hline & 21 & 5 & 4 & 9 & 1 & 0 & 0 & & & & 38 & 12.6 & 41.93 \\
\hline & 28 & 1 & 7 & 8 & 1 & 0 & 0 & & & & 37.2 & 11.8 & 42.86 \\
\hline Total & & 23 & 16 & 39 & 2 & 0 & 1 & & & & & & \\
\hline May & 5 & 3 & 10 & 13 & 2 & 0 & 1 & \multirow{4}{*}{0.08} & \multirow{4}{*}{0.00} & \multirow{4}{*}{0.05} & 37.4 & 15.6 & 43.71 \\
\hline & 12 & 6 & 1 & 7 & 0 & 0 & 0 & & & & 46.6 & 15 & 31.64 \\
\hline & 19 & 2 & 1 & 3 & 0 & 0 & 0 & & & & 46 & 16.8 & 37.14 \\
\hline & 26 & 27 & 3 & 30 & 0 & 0 & 4 & & & & 40.4 & 12.4 & 37.64 \\
\hline Total & & 38 & 15 & 53 & 2 & 0 & 5 & & & & & & \\
\hline \begin{tabular}{|l} 
June \\
\end{tabular} & 3 & 34 & 6 & 40 & 1 & 0 & 6 & \multirow{5}{*}{0.76} & \multirow{5}{*}{0.60} & \multirow{5}{*}{0.36} & 43.6 & 18.6 & 35.71 \\
\hline & 10 & 19 & 3 & 22 & 0 & 0 & 4 & & & & 44.4 & 18.8 & 36.29 \\
\hline & 17 & 29 & 5 & 34 & 1 & 0 & 5 & & & & 40.4 & 19 & 38.36 \\
\hline & 24 & 110 & 46 & 156 & 10 & 2 & 9 & & & & 43.4 & 20 & 38.86 \\
\hline & 30 & 161 & 29 & 190 & 7 & 1 & 10 & & & & 38.4 & 20 & 40.42 \\
\hline Total & & 353 & 89 & 4442 & 19 & 3 & 34 & & & & & & \\
\hline Total & & 6972 & 2507 & 9479 & 502 & 39 & 779 & & & & & & \\
\hline
\end{tabular}


Table (3): Population fluctuations of the brown soft scale, Coccus hesperidum its parasitoid, M. luteolus, encapsulated eggs, and its predator Chilocorus bipustulatus on ornamental plant during 2013/2014 seasons, at Assiut governorate.

\begin{tabular}{|c|c|c|c|c|c|c|c|c|c|c|c|c|c|}
\hline \multirow{3}{*}{$\begin{array}{l}\text { Month and } \\
\text { year }\end{array}$} & \multirow{3}{*}{ Date } & \multicolumn{6}{|c|}{ Weakly insect count/25 leaves } & \multirow{3}{*}{$\begin{array}{c}\% \\
\text { parasitism }\end{array}$} & \multirow{3}{*}{$\begin{array}{c}\% \text { Efficient } \\
\text { encapsulation }\end{array}$} & \multirow{3}{*}{$\begin{array}{c}\% \\
\text { predates }\end{array}$} & \multicolumn{3}{|c|}{$\begin{array}{l}\text { Meteorological } \\
\text { records }\end{array}$} \\
\hline & & \multirow[t]{2}{*}{ Nymphs } & \multirow[t]{2}{*}{ Adults } & \multirow[t]{2}{*}{ Total } & \multirow{2}{*}{$\begin{array}{l}\text { parasitized } \\
\text { (No. of } \\
\text { adults) }\end{array}$} & \multirow{2}{*}{$\begin{array}{c}\text { Efficient } \\
\text { encapsulation }\end{array}$} & \multirow{2}{*}{$\begin{array}{l}\text { Predated } \\
\text { (No. of } \\
\text { adults) }\end{array}$} & & & & $\begin{array}{r}\text { Temp } \\
\left({ }^{\circ}\right.\end{array}$ & rature & R.H \\
\hline & & & & & & & & & & & Max. & Min. & $\%$ \\
\hline July, 2013 & 7 & 326 & 81 & 407 & 18 & 2 & 53 & \multirow{4}{*}{3.96} & \multirow{4}{*}{1.72} & \multirow{4}{*}{2.61} & 40.8 & 20 & 42.42 \\
\hline & 14 & 255 & 48 & 303 & 10 & 0 & 48 & & & & 42.8 & 21.6 & 37.43 \\
\hline & 21 & 337 & 94 & 431 & 25 & 3 & 66 & & & & 44.6 & 22.4 & 41.71 \\
\hline & 28 & 383 & 103 & 486 & 40 & 3 & 51 & & & & 42.2 & 20 & 43.21 \\
\hline Total & & 1301 & 326 & 1627 & 93 & 8 & 218 & & & & & & \\
\hline August & 4 & 386 & 113 & 499 & 27 & 3 & 38 & \multirow{4}{*}{2.94} & \multirow{4}{*}{1.93} & \multirow{4}{*}{1.39} & 45.4 & 23.2 & 45.21 \\
\hline & 11 & 314 & 93 & 407 & 21 & 4 & 28 & & & & 41.6 & 22.2 & 44.5 \\
\hline & 18 & 255 & 50 & 305 & 11 & 2 & 22 & & & & 40.2 & 21.8 & 45 \\
\hline & 25 & 273 & 56 & 329 & 10 & 0 & 28 & & & & 38.2 & 19.8 & 49.71 \\
\hline Total & & 1228 & 312 & 1540 & 69 & 9 & 116 & & & & & & \\
\hline September & 1 & 213 & 62 & 275 & 11 & 2 & 16 & \multirow{5}{*}{2.21} & \multirow{5}{*}{1.07} & \multirow{5}{*}{1.10} & 38.6 & 20.6 & 56.64 \\
\hline & 8 & 206 & 51 & 257 & 9 & 0 & 23 & & & & 37.4 & 20.6 & 55.21 \\
\hline & 15 & 223 & 56 & 279 & 10 & 2 & 19 & & & & 35.8 & 18.8 & 55.29 \\
\hline & 22 & 143 & 43 & 186 & 11 & 0 & 14 & & & & 37 & 16.4 & 54 \\
\hline & 29 & 181 & 48 & 229 & 11 & 1 & 20 & & & & 41.6 & 18 & 45.93 \\
\hline Total & & 966 & 260 & 1226 & 52 & 5 & 92 & & & & & & \\
\hline \multirow[t]{4}{*}{ October } & 6 & 168 & 44 & 212 & 9 & 0 & 18 & \multirow{4}{*}{1.87} & \multirow{4}{*}{0.86} & & 44.2 & 18.6 & 45.21 \\
\hline & 13 & 188 & 53 & 241 & 10 & 1 & 22 & & & & 35.4 & 15.4 & 51.64 \\
\hline & 20 & 204 & 67 & 271 & 13 & 2 & 17 & & & 0.91 & 40.6 & 15.4 & 52.57 \\
\hline & 27 & 222 & 62 & 284 & 12 & 1 & 19 & & & & 37.8 & 16 & 47.86 \\
\hline Total & & 782 & 226 & 1008 & 44 & 4 & 76 & & & & & & \\
\hline November & 3 & 203 & 112 & 315 & 22 & 2 & 23 & & & & 35.4 & 15.8 & 52.93 \\
\hline & 10 & 236 & 133 & 369 & 30 & 3 & 26 & & & & 35.2 & 12.6 & 56.64 \\
\hline & 17 & 226 & 96 & 322 & 21 & 2 & 18 & 3.71 & 1.72 & 0.91 & 36.4 & 13 & 51.79 \\
\hline & 24 & 187 & 86 & 273 & 14 & 1 & 9 & & & & 27.4 & 8.8 & 61 \\
\hline Total & & 852 & 427 & 1279 & 87 & 8 & 76 & & & & & & \\
\hline December & 1 & 148 & 62 & 210 & 11 & 0 & 14 & & & & 23.8 & 5.6 & 62.57 \\
\hline & 8 & 155 & 74 & 229 & 20 & 1 & 22 & & & & 26.4 & 6.4 & 59.64 \\
\hline & 15 & 160 & 78 & 238 & 18 & 2 & 13 & 2.77 & 1.07 & 0.84 & 25.8 & 6.6 & 61.93 \\
\hline & 22 & 95 & 42 & 137 & 7 & 0 & 11 & & & & 23.8 & 5.6 & 65.14 \\
\hline & 29 & 87 & 46 & 133 & 9 & 2 & 10 & & & & 23.8 & 4.6 & \begin{tabular}{|l}
66.5 \\
\end{tabular} \\
\hline Total & & 645 & 302 & 947 & 65 & 5 & 70 & & & & & & \\
\hline
\end{tabular}




\section{Ghada S. Mohamed}

Table (3): Cont.

\begin{tabular}{|c|c|c|c|c|c|c|c|c|c|c|c|c|c|}
\hline $\begin{array}{c}\text { January, } \\
2014\end{array}$ & 5 & 54 & 113 & 167 & 9 & 1 & 13 & \multirow{4}{*}{1.41} & \multirow{4}{*}{0.86} & \multirow{4}{*}{0.45} & 29.2 & 5.2 & 63.71 \\
\hline & 12 & 32 & 106 & 138 & 11 & 2 & 11 & & & & 20.8 & 4.8 & 68.36 \\
\hline & 19 & 18 & 112 & 130 & 13 & 1 & 12 & & & & 22.8 & 4.2 & 67.5 \\
\hline & 26 & 3 & 16 & 19 & 0 & 0 & 2 & & & & 23.6 & 4 & 66.64 \\
\hline Total & & 107 & 347 & 454 & 33 & 4 & 38 & & & & & & \\
\hline February & 2 & 3 & 14 & 17 & 2 & 0 & 2 & \multirow{4}{*}{0.30} & \multirow{4}{*}{0.21} & \multirow{4}{*}{0.06} & 27.4 & 5.4 & 59.93 \\
\hline & 9 & 4 & 8 & 12 & 0 & 0 & 0 & & & & 23.8 & 4.2 & 59.57 \\
\hline & 16 & 1 & 13 & 14 & 2 & 0 & 1 & & & & 22.2 & 3 & 63.64 \\
\hline & 23 & 3 & 17 & 20 & 3 & 1 & 2 & & & & 32.4 & 8.6 & 61.5 \\
\hline Total & & 11 & 52 & 63 & 7 & 1 & 5 & & & & & & \\
\hline March & 2 & 0 & 0 & 0 & 0 & 0 & 0 & \multirow{5}{*}{2.73} & \multirow{5}{*}{0.00} & \multirow{5}{*}{0.04} & 31 & 7.6 & 57.5 \\
\hline & 9 & 3 & 13 & 16 & 2 & 0 & 1 & & & & 33.8 & 8.4 & 52.93 \\
\hline & 16 & 6 & 17 & 23 & 2 & 0 & 2 & & & & 24.4 & 6 & 61.29 \\
\hline & 23 & 4 & 9 & 13 & 0 & 0 & 0 & & & & 28.6 & 7.8 & 57.57 \\
\hline & 30 & 2 & 10 & 12 & 1 & 0 & 0 & & & & 31.4 & 9 & 57.93 \\
\hline Total & & 15 & 49 & 64 & 5 & 0 & 3 & & & & & & \\
\hline April & 6 & 11 & 6 & 17 & 1 & 0 & 1 & \multirow{4}{*}{0.09} & \multirow{4}{*}{0.00} & \multirow{4}{*}{0.01} & 28.43 & 11.97 & 52.5 \\
\hline & 13 & 4 & 2 & 6 & 0 & 0 & 0 & & & & 31.8 & 13.74 & 53.57 \\
\hline & 20 & 0 & 0 & 0 & 0 & 0 & 0 & & & & 33.66 & 15 & 46.43 \\
\hline & 27 & 2 & 3 & 5 & 1 & 0 & 0 & & & & 35.71 & 19.26 & \begin{tabular}{|l|}
45.14 \\
\end{tabular} \\
\hline Total & & 17 & 11 & 28 & 2 & 0 & 1 & & & & & & \\
\hline May & 4 & 8 & 2 & 10 & 0 & 0 & 0 & \multirow{4}{*}{0.26} & \multirow{4}{*}{0.00} & \multirow{4}{*}{0.02} & 36.6 & 14.8 & 42.64 \\
\hline & 11 & 10 & 4 & 14 & 1 & 0 & 0 & & & & 37.4 & 12.8 & 44.36 \\
\hline & 18 & 7 & 4 & 11 & 0 & 0 & 0 & & & & 38.4 & 15.4 & 42.29 \\
\hline & 25 & 8 & 11 & 19 & 5 & 0 & 2 & & & & 42.2 & 18.6 & 38.86 \\
\hline Total & & 33 & 21 & 54 & 6 & 0 & 2 & & & & & & \\
\hline June & 1 & 6 & 2 & 8 & 0 & 0 & 0 & \multirow{5}{*}{3.11} & \multirow{5}{*}{0.00} & \multirow{5}{*}{0.06} & 39.4 & 16.8 & 42.43 \\
\hline & 8 & 13 & 5 & 18 & 1 & 0 & 1 & & & & 40.6 & 20.4 & 42.93 \\
\hline & 15 & 18 & 3 & 21 & 1 & 0 & 1 & & & & 43.8 & 20.8 & 36.64 \\
\hline & 22 & 8 & 1 & 9 & 0 & 0 & 0 & & & & 43.8 & 19 & 41.14 \\
\hline & 29 & 13 & 4 & 17 & 1 & 0 & 3 & & & & 37.4 & 20.2 & 43.93 \\
\hline Total & & 58 & 15 & 73 & 3 & 0 & 5 & & & & & & \\
\hline Total & & 6015 & 2348 & 8363 & 466 & 44 & 702 & & & & & & \\
\hline
\end{tabular}


J. Plant Prot. and Path., Mansoura Univ., Vol. 5 (12), December, 2014

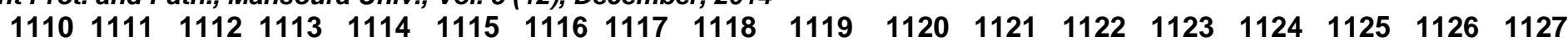

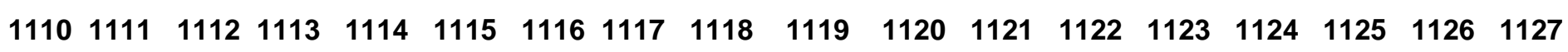

